\begin{tabular}{|l|l|l||}
\hline \multicolumn{2}{|c|}{ PublisherInfo } \\
\hline \hline PublisherName & $:$ & BioMed Central \\
\hline \hline PublisherLocation & $:$ & London \\
\hline \hline PublisherImprintName & $:$ & BioMed Central \\
\hline \hline
\end{tabular}

\title{
Regulatory T cells in human blood
}

\begin{tabular}{||l|l|l||}
\hline \multicolumn{2}{|c|}{ ArticleInfo } \\
\hline \hline ArticleID & $:$ & 70 \\
\hline \hline ArticleDOI & $:$ & $10.1186 /$ ar-2001-70200 \\
\hline \hline ArticleCitationID & $:$ & 70200 \\
\hline \hline ArticleSequenceNumber & $:$ & 27 \\
\hline \hline ArticleCategory & $:$ & Paper Report \\
\hline \hline ArticleFirstPage & $:$ & 1 \\
\hline \hline ArticleLastPage & $:$ & 4 \\
\hline \hline & & $\mid$ RegistrationDate $\quad: \quad 2001-8-2$ \\
& $:$ & Received $\quad: \quad 2001-8-2$ \\
ArticleHistory & $:$ & Accepted $\quad$ 2001-9-3 \\
& & OnlineDate $\quad 2001-9-3$ \\
\hline \hline ArticleCopyright & $:$ & Biomed Central Ltd2001 \\
\hline \hline ArticleGrants & $:$ & \\
\hline \hline
\end{tabular}




\begin{tabular}{|l|l|l|l|}
\hline ArticleContext & $:$ & 130753311 \\
\hline
\end{tabular}

Ranjeny Thomas, ${ }^{\text {Aff1 }}$

Aff1 University of Queensland, Australia

\section{Keywords}

Human, phenotype, regulatory $\mathrm{T}$ cells

\section{Context}

Three papers in the same issue of $J$ Exp Med and one in $J$ Immunol report the identification and characterization of human peripheral blood $(\mathrm{PB}) \mathrm{CD} 4+\mathrm{CD} 25+$ regulatory $\mathrm{T}$ cells (see Additional information [1-4]). Subsets of CD4+ and CD8+ T cells, as well as ?d T cells and natural killer T cells, have previously been shown to have regulatory properties. Thus, these cells are broadly known as Treg (see Additional information [5]). Specifically, human and murine CD4+ T cells with regulatory function have previously been generated in vitro in the presence of either immature dendritic cells (DCs) or monocytes in the presence of IL-10 (called "Tr1 cells"; see Additional information [6,7]). These CD4+ cells typically secrete large amounts of IL-10, low levels of IFN? and no IL-4/5.

\section{Significant findings}

Purified CD4+CD25+ cells were predominantly of the CD45RO+ HLA-DR + memory phenotype. Some constitutively expressed cytotoxic T lymphocyte-associated antigens-4. They expressed CD69 and CD40L upon activation, but proliferated poorly, made no IL-2, IL-4 or IFN? mRNA, and secreted little cytokine in response to mature DC. T-cell proliferation could be improved by incubation with IL-4 and IL-2. CD4+CD25+ T cells suppressed CD4+ T-cell proliferation and IFN? production in the presence of DCs, in a cell-contact-dependent manner. Either cognate interactions with antigen presenting cells (APCs), or ligation of CD3 could induce antigen-nonspecific suppression by this subset. CD4+CD25+ T cells could be expanded in vitro by incubation with anti-CD3 antibodies and cytokines.

\section{Comments}


The papers demonstrate that human regulatory $\mathrm{T}$ cells can be identified in fresh $\mathrm{PB}$ using the same markers as in the mouse, CD4 and CD25. The major limitation of these in vitro systems is the antigen nonspecificity of the suppression. In vivo there is evidence for 'linked' suppression of antigens copresented by APCs, but not widespread antigen-nonspecific suppression by Treg. Thus, our understanding of the physiology has not quite reached the stage of expansion of Treg cells in vitro for autoimmune immunotherapy in vivo. The relationship between CD4+CD45RO+CD25+ PB T cells and the $\mathrm{CD} 4+\mathrm{CD} 45 \mathrm{RO}+\mathrm{CD} 45 \mathrm{RBdim} \mathrm{T}$ cells that are enriched in RA synovial fluid (SF), remains puzzling. These populations both proliferate poorly, but only the SF T populations enhance B-cell immunoglobulin production (see Additional information [8]). Do these cells belong to the same lineage, with functional differences related to their microenvironment? Would infused CD4+CD25+ T cells change function in the disease environment? Can RA SF cells suppress activated T cell responses? Revisiting SF T cell function in light of the recent findings should improve understanding of disease pathogenesis as well as therapeutic development.

\section{Methods}

flow cytometry, MLR, cytokine production

\section{Additional information}

1. Jonuleit H, Schmitt E, Schuler G, Knop J, Enk AH: Induction of interleukin 10-producing, nonproliferating CD4+ $T$ cells with regulatory properties by repetitive stimulation with allogeneic immature human dendritic cells. $J$ Exp Med 2000, 192:1213-1222.

2. Levings MK, Sangregorio R, Roncarolo MG: Human CD25+CD4+ T regulatory cells suppress naive and memory $\mathrm{T}$ cell proliferation and can be expanded in vitro without loss of function. $J$ Exp Med 2001, 193:1295-1302.

3. Dieckmann D, Plottner H, Berchtold S, Berger T, Schuler G: Ex vivo isolation and characterization of CD4+CD25+ T cells with regulatory properties from human blood. $J$ Exp Med 2001, 193:1303-1310.

4. Baecher-Allan C, Brown JA, Freeman GJ, Hafler DA: CD4+CD25high regulatory cells in human peripheral blood. J Immunol 2001, 167:1245-1253.

5. Roncarolo MG, Levings MK: The role of different subsets of $\mathbf{T}$ regulatory cells in controlling autoimmunity. Curr Opin Immunol 2000, 12:676-683. 
6. Groux H, O'Garra A, Bigler M, Rouleau M, Antonenko S, de Vries JE, Roncarolo MG: A CD4+ T-cell subset inhibits antigen-specific T-cell responses and prevents colitis. Nature 1997 , 389:737-742.

7. Powrie F, Correa-Oliveira R, MauzeS, Coffman RL: Regulatory interactions between CD45RBhigh and CD45RBlow CD4+ T cells are important for the balance between protective and pathogenic cell-mediated immunity. J Exp Med 1994, 179:589-600.

8. Thomas R, McIlraith M, Davis LS, Lipsky PE: Rheumatoid synovium is enriched in CD45RBdim mature memory $\mathbf{T}$ cells that are potent helpers for $\mathbf{B}$ cell differentiation. Arthritis Rheum 1992, 35:1455-1465.

\section{References}

1. Jonuleit H, Schmitt E, Stassen M, Tuettenberg A, Knop J, Enk AH: Identification and functional characterization of human $\mathrm{CD} 4{ }^{+} \mathrm{CD} 25^{+} \mathrm{T}$ cells with regulatory properties isolated from peripheral blood. J Exp Med . 2001, 193: 1285-1294.

This PDF file was created after publication. 